\title{
Conditions for Initiating the Procedure of Poland's Withdrawal from the European Union
}

\section{Introductory remarks}

Polexit has emerged as an analytical category in studies conducted by lawyers, political scientists and sociologists constituting a 'Polish response' to the UK's motion to withdraw from the European Union. The objective of this article is to present both past and present determinants that need to be taken into account in the discussion on Polexit. This analysis of conditions that may lead to Poland's withdrawal from the EU adopts a sociological-political science perspective. While the legal perspective, albeit very complicated, as the British example shows, is to a larger or lesser extent predictable, the perspective adopted herein is more analytically challenging, as it requires taking into account variables that are difficult to predict. The content of the article is divided into two parts. The first one presents differences in the perception of relations between EU institutions and nation-states which result from different experiences of the 'old' and 'new' EU. The second part outlines the political dispute between the government of the Republic of Poland and the European Commission which could initiate a sequence of events leading to the scenario of Polexit becoming feasible.

The article argues that in the case of implementing the 'two-speed Europe' scenario, which seems likely given the results of the European Parliament elections, the conflict between the incumbent Polish government and European institutions will be further exacerbated. This scenario seems highly probable, as the ruling coalition stands a good chance of maintaining power in Poland after the parliamentary election. If the bargaining chip in the European dispute involves 'old' EU members urging a reduction in funds for the EU cohesion policy, or to condition the transfers of funds from this source on states' compliance with treaty obligations (such as the rule of law, or joining the euro zone), the scenario providing for a referendum regarding Poland's withdrawal from the European Union will become realistic. The decision on this matter will of course depend on the political calculations of whether, in the opinion of politicians of the ruling party, their electorate can be mobilized. To a large extent, this electorate is Eurosceptic, if not outright anti-EU.

\section{The essence of the dispute between 'old' and 'new' European Union countries}

Having regained their political and economic sovereignty in 1989, the states and societies of Central and Eastern Europe immediately faced a dilemma regarding their position in Europe (Delanty, 1999; Offe, 1999; Brubaker, 1998). Several scenarios 
were possible at the time. One involved the empowerment of former partners cooperating within the Mutual Economic Assistance Council (Comecon) and the Warsaw Pact. Another scenario provided for close cooperation of the former European satellites of the Union of Soviet Socialist Republics (USSR) that would fill the space between the post-Soviet area and Western European countries, most of which were then members of the European Economic Community (EEC) and the North Atlantic Pact (NATO). An example of an alternative solution to the Warsaw Pact and the North Atlantic Pact was the NATO-bis concept, which assumed the establishment of a military system of Central European countries that had previously belonged to the dissolved Warsaw Pact. This proposal was put forward by the President of the Republic of Poland Lech Wałęsa in March 1992, during his visit to Germany (Kupiecki, 2016). Poland aspired to take the role of coordinator of integration processes in the countries of Central and Eastern Europe. Interestingly, the contemporary Three Seas Initiative is a more or less explicit reference to this scenario, the difference being that, after 1989, it was about Central European politicians seeking an alternative to the relationship defined by the dominant position of the Soviet Union, while the West had yet to design a proposal for Central and Eastern Europe. There is another extremely important difference, namely that some politicians of the 'old' EU countries treat the Three Seas Initiative as an instrument to exercise pressure, or even blackmail, or in terms of disloyalty. The government of Law and Justice (PiS) sought support for the Three Seas Initiative in the Visegrad Group countries (Hall, 2018, p. 201).

The last scenario proposed, then, has been implemented, integrating this part of Europe with Western Europe, whereby the 1990s slogan of the CEE 'returning to Europe' has been made material.

The problem with this part of Europe, however, was that 1939 interrupted the discussion initiated after 1918 about the national, ethnic, and regional identity of citizens of the states that had emerged after the collapse of the Ottoman Empire, the Russian Empire, Austria-Hungary and the consequent border changes in the area of the German Empire (the Second Reich). The interwar period was too short to arrive at any permanent solutions to this search for identity. The years of World War II, during which the German occupying authorities took advantage of the ethnic and national antagonisms existing in this part of the continent, exacerbated the conflicts even more (for instance, fights between Croats and Serbs, the Volkslist in Upper Silesia). In the period of communist domination, the discussion on identity was frozen. It was revived almost immediately after Central European states and societies regained sovereignty. At the same time, Western Europe was developing its integration project in the course of a debate which was ultimately concluded with the Maastricht Treaty, or the Treaty on European Union. The treaty strengthened the tools for implementing regional policy, which is an important element of structural policy. This reinforcement partly consisted of the introduction of Chapter 4 to the treaty, which established an additional advisory structure including representatives of regional and local communities and was named the Committee of the Regions (Treaty on European Union). The establishment of this institution became an important element of the discussion on the relationship between member states and EU institutions. For supporters of the development of the European project, this was an important element of this process. However, more conservative 
circles treated this strengthening of the position of regions as undermining the position of central authorities. It was too early for the representatives of CEE countries to participate in this discussion. The issue of relations between nation-state and the European Union could not emerge in the course of membership negotiations, because for a country to access the European Union it was a prerequisite to adopt the acquis communautaire, or the body of EU law encompassing the set of legal rules (treaties), as well as EU judicature. A potential difficulty in the implementation of regional policy faced by Central European states was their communist past. CEE states were centralized, the discussion on regional identity had been persecuted, or at least marginalized, as opposing the ideological principle of building an 'internationalist society.' This is not to mean that the opponents of accession to the EU did not address this problem in the discussion on the consequences of accession. They expressed their concerns, issuing warnings against the loss of cultural identity to be experienced in CEE states after their accession. In Poland, this was one of the most important arguments wielded by the opponents of Poland's membership of the European Union. However, due to the high support for accession among Poles, this argument was not decisive for the results of the European referendum. For Poles, joining the European Union was a chance to overcome Poland's civilizational backwardness and catch up with Western Europe, and to achieve a living standard comparable to that of Western European societies. The discussion on cultural identity and relations between member states and EU institutions was held later. From the very beginning, this discussion involved a dispute about to what extent Poland's future EU membership would lead to the dilution of its culture. The opponents of Poland's EU accession emphasized this argument. The same argument is raised today on the occasion of assessing the benefits and losses after 15 years of Poland's membership of the European Union.

The first, significant differences in the vision of the future of the European project as seen by 'old' and 'new' Europe became apparent when discussing the provisions of the Treaty establishing a Constitution for Europe, or the Constitutional Treaty, adopted by member states at the summit in Rome in October 2004. In the discussion on the treaty, considerable controversy was aroused with reference to the content of the preamble, which was to define the system of values that constitute the European Union. An initial proposal was to refer to the culture of the ancient Greeks and Romans, and the ideals of the French Revolution, which was bound to arouse criticism of the Church, the European Christian Democrats and governments of many member states. As a compromise solution, a reference to "humanistic and religious traditions" was proposed without mentioning a particular religion. Even this phrasing failed to satisfy the supporters seeking a reference to Christian values to be made in the preamble. A reference to the Christian tradition was advocated by Pope John Paul II and the government of Poland, with its post-communist Prime Minister Leszek Miller. A similar position was presented by representatives of Ireland, Italy, Portugal, Spain, Lithuania, Slovakia and Austria, that is of the countries where the Catholic Church exerted a significant impact on axiological issues. The opponents of entering the Christian system of values into the preamble, namely Belgium, France and Denmark, stressed the principle of the separation of church and state and the fact that in the future Muslim countries, Bosnia and Herzegovina, Albania and Turkey might also join the EU. The treaty 
has not been adopted and the disputes over ideological issues have remained; it seems that in the discussion on potential future '...exits' they will play a significant, albeit not dominant role, becoming a kind of addition (or excuse), because economic issues and the distribution of power in EU institutions will always come first.

From the point of view of the subject of this article, a question should be posed of whether the rise of sentiments unfavorable for the European Union, both in the 'old' and 'new' member states, represents 'anti-EU populism,' as Euro-enthusiasts would have it, or results from a 'European awakening,' as Euroskeptics would like it. To facilitate the analysis of the causes of the conflict between the two parts of Europe, Chantal Delsol, a philosopher of politics who classifies herself as a liberal neo-Conservative, introduces the concept of conservative revolution, which she sees as "a response to the revulsion triggered by the modern evolution towards capitalism and materialism. It hates the bourgeois, the prototype of materialists. It appeals to the foundations provided by ethical and religious principles, nationalism, and being down to earth - or realism against utopias. In contrast to individualism, the conservative revolution promotes a communitarian spirit. It desires the elite rather than egalitarianism. The German conservative revolution attacked all political parties and the decadent and unstable Weimar Republic. Central European societies are rebelling against a modernity that the European Union would like to impose on them. Basically, it is always about fighting materialism, the decadence of morals and excessive universalism and defending the roots, ethical spirituality and identities. [...] The conservative revolution is the current of those who believe that the modernization process endangers fundamental values and substantial principles" (Delsol, 2018). The question of values that are important for both 'old' and 'new' Europe is whether they are the same for both parts. Western Europe means multiculturalism, universalism, globalism and a market society. Central Europe means cultural identity, spirituality and social solidarity as the legacy of the forty-year experience of social security that is becoming more and more idealized over time. Most often, this specific 'ostalgia' is not overtly articulated, as it would indirectly legitimize the ideology of the communist state, and is rather expressed as negative assessments of modern times regarding, for instance, the sources of unfair social divisions that arose after 1989. Another manifestation of 'ostalgia' is the fear of losing the security of culture, understood as the pursuit of preserving one's distinctiveness in the face of the cultural openness resulting from the accession of CEE states to the European Union. Multiculturalism is often freely contested by politicians, who describe it in terms of the German concept Multikulti. Initially, it was synonymous with the successful integration policy of immigrants who arrived in the Federal Republic of Germany as Gastarbeiters [foreign or immigrant workers]. After 2015, however, the term started to symbolize difficulties in the integration of immigrants. This issue became particularly evident in the course of seeking ways to solve the problems triggered by the migration crisis. The thesis that the aversion to immigrants - a sentiment present among European societies - is fueled by politicians so that they can politically profit from it later on does not seem accurate. The attitudes towards immigrants are rooted in a real fear of dangers associated with the influx of strangers. Therefore, the

1 This term describes the longing of the society of the 'new' German lands for the social solutions of the German Democratic Republic. 
question arises about the limits of the approval for political activities aiming at maintaining the status quo ante. If authority is won through democratic principles, can these principles be rejected afterwards? Desol asks the question of the limits of 'illiberal democracies:' "has the authority been elected in order to restrict freedom? Or maybe voters have been cheated? Another important question is why and in the name of what does the authority limit freedom?" (Ibid.). Desol answers her own questions in the following manner: "the illiberal democracy has discovered that there is one and the same worldview behind it, and the logic of confrontation convinced the illiberal democracy that Western Europe has fallen victim to ideological madness. At the same time, it sees itself as the only voice of reason and realism - the victory of the "common sense of ordinary people"" (Ibid.).

Proponents of this way of exercising policy argue that freedom has its limits, which Western democracies exceed, making them unacceptable for Eastern European societies. Illiberal democracy assumes that restricting economic freedom is justified if it contributes, for example through economic patriotism, to minimizing the negative outcomes of globalization processes. Individual emancipation also has its limits, usually defined by tradition and principles of social life. Supporters of the illiberal democracy approach economic and moral liberalisms as threats. The illiberal democracy doctrine departs from democracy, which is considered contrary to the principles of tradition and cultural experience.

Western European societies view the spread of the illiberal democracy with disbelief. The question arises as to how it is possible that countries and societies indicated as examples of successful economic, political and cultural transformation are stepping off this path. This is difficult to accept because they were supposed to be a model for other countries whose societies are still under authoritarian or totalitarian rule.

When Europe is celebrating the sixtieth anniversary of the Treaties of Rome, and Poland is celebrating fifteen years of EU membership, Michał Kleiber poses a surprising question: Europe - together or separately? This is, of course, a rhetorical figure which, however, reflects an actual problem. This is a question about the shape of the European Union and the role of Poland in the discussion on the future of the European project. "Today marks a historic moment that may determine the shape of our continent for years. The stakes are enormous - we will either overcome our prostration in strategic thinking about Europe or face growing problems threatening Europe with its gradual disintegration and, as a consequence, its marginalization on the global scale" (Kleiber, 2018). The results of elections to the European Parliament failed to satisfy the expectations of supporters of a radical redefinition of relations between the European Union and nation-states, who had hoped to strengthen their position. Nevertheless, the question about the causes of the integration crisis remains. Kleiber identifies the following symptoms of the crisis: "the criticism of the EU's efficiency and legitimacy of its structures or the loss of confidence of member states' citizens in the communitarian idea itself are widely described and discussed. The belief that far-reaching changes, or even a renaissance of the EU are needed is slowly breaking

${ }^{2}$ In illiberal democracies the authorities are democratically elected, but begin to limit freedom immediately after the elections. The most frequent example given of this was the National Socialist Party taking power in Germany in 1933. 
through. However, we rarely come across substantive analyses of the reasons for the current state of affairs, and such uncertainty only intensifies the negative perception of the EU, inside and outside. Traditional divisions into the left and the right are becoming blurred in member states and replaced by the growing gap between integrators and supporters of far-reaching national autonomy. Both sides have trouble not so much even with the search for some compromise solutions, but rather with listening to each other's arguments in the first place. Supporters of nation-states are accused, for example, of an inability to understand the need to consolidate the unity of the European community. And yet many of them are guided by quite rational premises, claiming that only political organizations that guarantee the real participation of people in exercising power can be effective in political practice, and it is difficult to argue that the today's EU is effective" (Ibid.). According to Michał Kleiber, the above weaknesses can be overcome by establishing an effective institutional order that will instill a sense of security in people, which will result from a set of regulations defining social interactions that will be rational, understandable and acceptable by member states' societies. He proposes transforming the technocratic model of EU functioning into a civic model "so that everybody, not only today's Euro-enthusiasts, is proud of their Europeanness and treats Europe as their second, larger homeland - in a way that does not weaken, but actually strengthens our own ethnic-cultural identity" (Ibid.). Let us hope that the discussions, dialogues and disputes that had taken place during the European Parliament election campaign in member states contributed to increased voter turnout on the one hand, and on the other indicated an increased interest in European integration. In Poland, the turnout exceeded 40 percent. However, it would be an exaggeration to conclude on this basis that this evidences Poles' increased interest in European issues. The increase in turnout was the result of the main political forces treating the elections as a prelude to the parliamentary elections in the fall. The victory was supposed to ensure a good starting position before these approaching elections.

\section{The areas of difficult dialogue between the government of the Republic of Poland and the institutions of the European Union}

From the very beginning of the rule of the Law and Justice (PiS) political party in the fall of 2015, it was clear that the rhetoric regarding relations between the Polish authorities and the European Union that had been employed by PiS politicians for the eight years while in the opposition, was not just an element of the political game aiming to win the anti-EU electorate and the support of the Church. Behind this rhetoric was the desire to change this relation as expressed by the PiS slogan about 'Poland rising from its knees.' The change was manifested in the most spectacular way by the absence of EU flags during the speeches of Prime Minister Beata Szydło. Politicians of the ruling party were of the opinion that the European Union should be reformed, which could only be done by amending the treaties. For this to happen, however, other member states would have to be persuaded to support this solution, which required the ability to create a coalition capable of making changes. The question arises, then, of whether the PiS politicians who are in charge of foreign policy, including policy 
towards the European Union, stand a real chance of building such a coalition. Another important matter involves the presentation by PiS politicians of the proposed changes in the operations of the European Union which will be a decisive factor in sparking a pan-European discussion on the change of treaties. Presenting its vision of the EU, PiS refers to the idea of a 'Europe of Fatherlands' developed by Charles de Gaulle, which today would restrict the European project to economic cooperation, while maintaining solidarity programs such as free flows of labor, cohesion policy and the common agricultural policy. PiS wants a European army, joint foreign policy and a president whose powers were defined by Jarosław Kaczyński [the founder and leader of PiS - translator's note] in an interview with the "Rzeczpospolita" newspaper, as follows: "his powers should be strictly defined, but extensive, for example, to exercise the EU's foreign policy towards large entities, such as Russia, China, the United States and India; of course, while individual countries maintain their own foreign policies. His authority would also involve commanding an army, which should have two great fronts - the eastern and southern one" (Szułdrzyński, 2016). Another change should be implementing the principle of the EU operating on a basis of law rather than the arbitrary decisions of EU politicians or the leaders of major EU countries (France and Germany). According to Jarosław Kaczyński, this goal could be achieved by including it in the association agreement "thereby eliminating the creation of law enforcement at the European Union's level" (Ibid.). These postulates seem difficult to implement on account of their inconsistency. For example, what powers would the President of the European Union exercise if he was responsible for foreign policy while member states maintained full sovereignty in this area? Would it be possible to keep EU budgets and convince member states to continue their contributions if such a change took place? A confederation with an institutionalized budget and without an institution distributing funds is a risky solution, because it is national governments that would have to agree on the principles of the common market and the distribution of funds for agricultural and cohesion policies. The operation of this mechanism is difficult to imagine if controversies arise in the mutual relations between member states, such as those currently dividing, for example, Poland and France. The assessment of how feasible it is for Poland to create a coalition of member states capable of initiating a discussion about changing the treaties has resulted in politicians of the ruling party postponing it until circumstances are more favorable. However, in light of the results of the European Parliament elections, this does not seem to happen over the next five years.

In this situation, PiS politicians are focusing on presenting their vision of (plan for) Europe. During a speech delivered on July 4, 2018 at the European Parliament, Prime Minister Mateusz Morawiecki presented the "Polish plan for Europe," and reiterated its main assumptions during another speech given on the occasion of the 15th anniversary of Poland's membership of the European Union. The Prime Minister stated that in the face of the crisis of the European project "its democratic legitimacy must be strengthened. You can call it populism, but sooner or later a question will have to be answered of whether responding to citizens' expectations is really populism or rather the essence of democracy. Europe is experiencing a democratic awakening that shows that we need to renew the social contract that has created the great success of postwar integration. This contract has been about creating a sense of security and an eco- 
nomic policy that offered relative prosperity to everyone. Today, we must annex this contract by restoring a sense of security and hope that our children will live a better life than ourselves. Only this can rebuild trust in the European project" (Morawiecki, 2018). Morawiecki refers to the words of Jarosław Kaczyński who believes that it is necessary to return to the Gaullist concept of a 'Europe of Fatherlands,' which should be adapted to modern challenges. "As part of such an intelligent adaptation, we suggest focusing on three main points. Firstly, Union 4.0, i.e. the European Union as the avant garde of industrial revolution and a deepened single market. Secondly, a secure Union, which is aware of the geopolitical challenges it is facing and is ready to respond to them with one, united voice. Thirdly, a civil Union, i.e. a socially sensitive Union, supporting its citizens in the face of powerful global corporations. A solidary Union" (Ibid.). In the opinion of Prime Minister Morawiecki, the need to combat the inequalities emerging in Europe should shape the discussion on spending in the next programming period. He urges that the financing of new policies and challenges facing the European Union be not at the expense of the cohesion policy which is for him "the essence of the European Union." Without doubt, this is a reaction to these currents in the discussion on the future financial framework in which smaller funds are to be allocated to the cohesion policy, whose main beneficiaries are CEE countries. Assessing the 15 years of membership, the Prime Minister expressed his expectation that the egoisms of stronger players would not prevail in Europe. "A Europe without egoisms and a solidarity Europe is better than a two-speed Europe. A Europe of family values is more secure and friendly than a Europe of revolution and cultural experiments" (Przemówienie..., 2019). This undoubtedly is a response to the vision of the future of Europe supported by President Macron, who believes that the eurozone is the true center of the European Union. This is clearly unacceptable for the government in Warsaw. "In his programmatic book published before the election, he [Macron - C.T.] opted for creating a separate eurozone budget that would be used to finance joint investments, support disadvantaged regions and interventions in crisis situations" (Hall, 2018, p. 199). Thomas Assheuer argues that the French President can present a vision of a Europe capable of "liberating the public from the cobwebs of Brussels technocracy" (Assheuer, 2017). In the opinion of many experts on European issues, Emmanuel Macron is currently the only European leader who can convince the citizens of the European Union that the EU version of Europe can protect them from globalization. "The French President is also the most conspicuous adversary of the camp that "while being in the EU, is distancing itself from the EU and organizing an internal exit.' $\mathrm{He}$ is seeking how to escape from multiculturalism by symbolically returning home, to a cultural past, which he probably has never left himself" (Ibid.). According to Marek Prawda, "unless we focus on solving our real problems, we will squander our strength in destructive debates that will only reinforce internal divisions. Therefore, we have to embark on a serious conversation about Europe and believe in the driving force of the following narrative: 'either we will manage to forge the crumbling and trouble-ridden landscapes of nation-states of today into a European unity, or we will witness progressive decomposition"' (Prawda, 2018, p. 13). The only common denominator of the two narratives of the future of Europe is that they exist. The analyses of the sources of the crisis, and the strategies for overcoming it are radically different. On May 26, 2019, 
the majority of Europeans apparently trusted the current elite, and gave them time until 2024 to work out a compromise.

The basic source of the radical difference of opinions between the Polish government and European institutions, however, is the state of the rule of law in Poland. One of the first political decisions made by the PiS government, and supported by President Andrzej Duda, of the same political affiliation, was to challenge the June 2015 decision of the Polish Parliament regarding the appointment of five judges to the Constitutional Tribunal. Three out of four of the judges were elected to replace the judges whose tenure was to expire during this term of parliament. The other two were to replace the judges whose tenure did not expire until the next parliamentary term. The newly elected parliament adopted a resolution cancelling the election of all the judges and appointed five new ones; on December 22 it also adopted an act amending the Act on the Constitutional Tribunal. The core of this amendment concerned the operational principles of the Tribunal. The most important one requires that cases be examined in the order in which they were submitted and introduces the possibility of disciplinary proceedings being initiated against a judge of the Tribunal at the request of the Minister of Justice or the President. These decisions caused the first concerns of the European Commission. In July 2017, the parliament adopted a package of laws changing the system of operation of common courts in Poland. This triggered a reaction from the European Commission which recommended taking into account the suggestion regarding the elimination of potential threats to the rule of law in Poland. In case relevant steps were not taken, a decision would be made to initiate the procedure under Article 7 of the Treaty on European Union. ${ }^{3}$ On December 20, 2017, the European Commission decided to launch the provisions of Article 7 against Poland. This moment can be seen as marking the beginning of the 'cold war' in mutual relations which continues to date. Both parties announce their success at every opportunity. The most recent one involved the Polish delegation opposing the election of Frans Timmermans as President of the European Commission, since the politicians of the ruling party in Poland see him as the main reason for the poor mutual relations. Nevertheless, it seems more than likely that Frans Timmermans will keep the office of first vice-president of the European Commission and his determination to ensure that all recommendations concerning the rule of law in Poland are implemented is unlikely to wear off. The latest spectacular event in this dispute involved the judgment of June 24, 2019 passed by the Court of Justice of the European Union (CJEU). CJEU judges ruled that applying the provisions lowering the retirement age of judges of the Supreme Court in Poland to the incumbent judges is not legitimate and violates the principle of tenure of judges, which is inextricably linked to their independence, thereby making the said provisions contrary to EU law and the Constitution of the Republic of Poland. In November 2018, the Supreme Administrative Court of Poland (NSA) submitted to the CJEU an

${ }^{3}$ Art. 7. The Council finding that there is a clear risk of a serious breach by a Member State of the EU's values. Item 1 of this Article stipulates the following: "On a reasoned proposal by one third of the Member States, by the European Parliament or by the European Commission, the Council, acting by a majority of four fifths of its members after obtaining the consent of the European Parliament, may determine that there is a clear risk of a serious breach by a Member State of the values referred to in Article 2. Before making such a determination, the Council shall hear the Member State in question and may address recommendations to it, acting in accordance with the same procedure." 
inquiry on the procedure to appeal against the resolutions of the National Council of the Judiciary (KRS) appointing candidates for judges to the Supreme Court, which is still pending. In this context, the Supreme Administrative Court pointed out, among others, the rules for the selection of members of the National Council of the Judiciary, whereby the majority of judges are elected by the parliamentary majority and not by judges, as was the case before, which in the opinion of the Supreme Administrative Court does not guarantee the Council's independence from politicians.

\section{In lieu of conclusions}

Contrary to what supporters of the radical redefinition of relations between nationstates and the institutions of the European Union had hoped for, the results of the elections to the European Parliament did not bring any significant changes in the balance of power in this institution. This means that concerns that it might be possible to start discussions on amending treaties are no longer valid. It is an unquestionable success of PiS to have increased the number of their representatives in the European Parliament, but this will not translate into the possibility to implement the 'Polish plan for Europe,' as PiS will be part of the European Conservatives and Reformists (ECR) faction, constituting a mere 62 MEPs. This number of votes does not ensure having real influence on important decisions taken by the EP. Their alliance with the Euroskeptic right, united within the newly created Identity and Democracy group with 73 MEPs, will account for only 135 votes (18\%) out of the 751 members of the European Parliament.

It is the opposite of what PiS might consider to be a success that the states from the Visegrad Group have been marginalized in the current European Parliament. The Visegrad Group, alongside Italy, Ireland, Estonia and Lithuania, managed to block Frans Timmermans from running for President of the European Commission. PiS politicians recognized this as a success and a harbinger of effective future cooperation on other matters. One cannot fail to notice, however, that 'in return' for the elimination of Timmermans this region of Europe has no representative in the highest positions of the European Union. The office of the President of the European Commission will probably be taken by Ursula von der Leyen from Germany, Charles Michel from Belgium will be the head of the European Council, EU diplomacy will be headed by a Spaniard, Josep Borell, and the French woman Christine Lagarde will manage the European Central Bank. An Italian, David Sassoli, will become the President of the European Parliament. As a consequence, the division into 'old' and 'new' Europe will further solidify. This may make it easier for the French President to implement his vision of closer integration within a smaller group with a separate budget. This is the shortest way to Polexit.

\section{Bibliography}

Assheuer Th. (2017), Macrons grosser Moment. Der französische Präsident setzt auf eine Karte. Er ist Europas letzte Hoffnung, "Die Zeit", 19.10.2017.

Brubaker R. (1999), Nacjonalizm inaczej. Struktura narodowa i kwestie narodowe w Nowej Europie, Wydawnictwo Naukowe PWN, Warszawa-Kraków. 
Delanty G. (1999), Odkrywanie Europy. Idea, tożsamość, rzeczywistość, Wydawnictwo Naukowe PWN, Warszawa-Kraków.

Delsol Ch. (2018), Rewolucja konserwatywna przechodzi przez Europe, "Wszystko co Najważniejsze", Warszawa.

Hall A. (2018), Wpływ prezydentury Emmanuela Macrona na rozwój integracji europejskiej i interesy Polski, in: Polska w Unii Europejskiej. Nowe wyzwania, eds. J. Barcz, R. Kuligowski, M. Szewczyk, E. Szklarczyk-Amati, Komisja Europejska Przedstawicielstwo w Polsce, Warszawa.

Kleiber M. (2017), Europa - razem czy osobno?, "Wszystko co Najważniejsze”, Warszawa.

Kupiecki R. (2016), Organizacja Traktatu Pótnocnoatlantyckiego, Wydawnictwo Ministerstwa Obrony Narodowej, Warszawa.

Morawiecki M. (2018) Polski plan dla Europy, "Wszystko co Najważniejsze”, Warszawa.

Offe C. (1999), Drogi transformacji. Doświadczenia wschodnioeuropejskie i wschodnioniemieckie, Wydawnictwo Naukowe PWN, Warszawa-Kraków.

Prawda M. (2018), Krajobraz po szoku, in: Polska w Unii Europejskiej. Nowe wyzwania, eds. J. Barcz, R. Kuligowski, M. Szewczyk, E. Szklarczyk-Amati, Komisja Europejska Przedstawicielstwo w Polsce, Warszawa.

Przemówienie premiera Mateusza Morawieckiego z okazji 15. rocznicy przystapienia Polski do Unii Europejskiej (2019), https://www.premier.gov.pl/wydarzenia/aktualnosci/przemowieniepremiera-mateusza-morawieckiego-z-okazji-15-rocznicy.html, 30.06.2019.

Szułdrzyński M. (2016), Musimy wyjść z inicjatywa zmian w UE, "Rzeczpospolita” of 27.06.2016.

Traktat o Unii Europejskiej (1992), Dz. Urz. UE C 191, 29.07.1992.

Traktat z Amsterdamu zmieniajacy Traktat o Unii Europejskiej, Traktaty ustanawiajace Wspólnoty Europejskie oraz niektóre zwiazane z nimi akty, http://oide.sejm.gov.pl/oide/index.php?option $=$ com_content\&view=article\&id=14425\&Itemid $=426$.

\section{Summary}

Polexit is a concept that emerged in the political science discourse when the United Kingdom held a referendum on its continued membership of the European Union on June 26, 2016. The article analyzes the reasons which facilitate a discussion on the withdrawal of Poland from the European Union. On the one hand, this results from disputes on the direction of the evolution of the European project between 'old' and 'new' member states. On the other, its intensity is affected by the dynamics of the dispute between the Polish government and the European Commission on the state of the rule of law in Poland. For supporters of a change in relations between European institutions and member states, the European parliamentary elections offered an opportunity of starting a discussion on the change of treaties. However, due to the fact that proponents of treaty changes failed to win the appropriate number of seats, the vision of an EU of 'two speeds' is becoming realistic. This may mark the beginning of a sequence of events concluded with a referendum on the withdrawal of Poland from the European Union.

Key words: Polexit, conservative revolution, illiberal democracy, rule of law

\section{Uwarunkowania wszczęcia procedury wystąpienia Polski z Unii Europejskiej}

\section{Streszczenie}

Polexit to pojęcie, które pojawiło się w dyskursie politologicznym w momencie, kiedy w Wielkiej Brytanii w dniu 26 czerwca 2016 roku przeprowadzono referendum dotyczące dal- 
szego członkostwa tego państwa w Unii Europejskiej. W artykule tym dokonano analizy przyczyn, dla których stała się możliwa dyskusja na temat wystąpienia Polski z Unii Europejskiej. Jest ona, z jednej strony, efektem sporów na temat kierunków ewolucji projektu europejskiego, jaki daje się zauważyć w dyskusji między „starymi” i „nowymi” państwami członkowskimi. Z drugiej, jej intensywność jest warunkowana dynamiką sporu, jaki rząd polski toczy z Komisją Europejską, na temat stanu praworządności w Polsce. Dla zwolenników zmiany relacji między instytucjami europejskimi a państwami członkowskimi wybory do Parlamentu były szansą na rozpoczęcie dyskusji dotyczącej zmiany traktatów. Jednak z uwagi na fakt, że zwolennicy zmiany traktatów nie zdobyli odpowiedniej liczby mandatów, staje się realną realizacja wizji Unii „dwóch prędkości”. Może to oznaczać początek sekwencji zdarzeń, których końcem będzie referendum w sprawie wystąpienia Polski z Unii Europejskiej.

Słowa kluczowe: polexit, konserwatywna rewolucja, demokracja illiberalna, praworządność 